\title{
Gaps and Bits: Conceptualizing Measurements for Digital Divide/s
}

\author{
Karine Barzilai-Nahon \\ The Information School, University of Washington, Seattle, Washington, USA
}

Three arguments are raised in this article with regard to the indices used to measure the digital divide. First, I criticize policymakers who rely on simplistic measures of the digital divide, at the expense of a thoughtful analysis of (1) the purpose of the tool, (2) the level of observation, and (3) the method of approaching the data. Second, I argue that networks and associated technologies are not neutral artifacts but are political and social spaces in their structure as well as in their content levels. Accordingly, we need to factor in the context as an important actor in conceptualizing and measuring the digital divide. Third, two general types of indices are used for the measurement of the digital divide(s): focused monotopical indices and comprehensive indices. Monotopical indices are more widely available, while comprehensive ones are rare. $I$ argue that policymakers need to promote comprehensive indices over monotopical indices. Finally, I present a conceptual definition of the digital divide and a framework for developing a comprehensive index to measure it.

Keywords access, digital divide, e-readiness, inclusion, inequality, information society indicators

"To be conscious that you are ignorant is a great step to knowledge.” Benjamin Disraeli (18041881)

There has been much discussion and debate about the definition of the digital divide and of the empirical analyses of its components (Chen, 2004; Compaine, 2001; Cooper, 2002; Dewan \& Riggins, 2005; DiMaggio et al., 2004;

Received 22 August 2005; accepted 3 June 2006.

I was lucky to work on the article drafts in collaboration with Sheizaf Rafaeli, and I am grateful for all his help and mentorship. I thank Bob Mason for the enlightening comments, and the anonymous referees who guided us toward sharper arguments. Finally, the stimulating debates in the 2006 Access to Knowledge (A2K) conference in Yale Law School contributed much to refining this article.

Address correspondence to Karine Barzilai-Nahon, University of Washington. E-mail: karineb@u.washington.edu; web site: http://www.ischool.washington.edu/karineb
Hargittai, 2003; Norris, 2001; Warschauer, 2003). In the 1990s the traditional focus was mainly on infrastructural access. Today the discourse about the digital divide has expanded to other concerns and factors that generate digital inequality (e.g., differential modes of use and economic development) (Benkler, 2006; Bridges.org, 2005b; ITU, 2003; Lebo, 2003; Wilson, 2006). While the traditional access-oriented thinking focused on questions related to measures such as ownership, availability, and affordability of infrastructure, now the focus is moving beyond technology to the users. Still, in both analyses-traditional and contemporary - the emphasis is on single-factor, or monotopical, ${ }^{1}$ relations rather than on integrative frameworks and measurements.

Elaboration on what exists and what could be a more useful way of conceptualizing the digital divide (and thereby its measurement) is put forward in the following sections.

\section{CALLING FOR A POLICY FRAMEWORK}

There are two ways of approaching the measurement and analysis of the digital divide: through atomic and monotopical lenses or through holistic and comprehensive lenses. The choice of an appropriate index or set of indices is, of course, of vital importance for both theory and practice. The decision whether to employ monotopical or comprehensive lenses should take into consideration (1) the purpose of the tool, (2) the level of observation, and (3) the method of approaching the data. Each of these considerations is a matter of much debate and tension. In this section I identify and reflect on key issues for construction of effective tools for measuring the divide.

\section{Purpose of the Tool: Can "Comparative" and "Contextual" Live Together?}

Decision makers often fall into the trap of seeking data that exist, instead of putting in the effort to first systematically conceptualize the digital divide, operationalize it as appropriate to the context, and only then collect data. 
Consider the position of the Bush Administration (Cooper, 2002, 2004), which is nicely captured by the much quoted remarks of Michael Powell, the former U.S. Federal Communications Commission Chairman, who compared the digital divide to a "Mercedes divide," said, "I would like to have one, but I can't afford one.",

This quote illustrates the tendency of the policymakers to approach the divide from a technologically deterministic perspective. Single factors such as "access" are convenient since they are easy to measure. Additionally, these simple measures can be used to influence public opinion since lay people can relate to them. However, the major reason policymakers gravitate toward technologically deterministic measures is their need to justify allocation of resources, a task that is made easier if they can create benchmarks and compare one nation to another against this benchmark. Policymakers like to have an "objective" comparative tool. In other words, the fact that these measures may be appropriate in particular contexts is given little thought.

The problem is that the context of the unit of analysis is overlooked. Often the benchmark is set artificially according to some lowest common denominator for all countries, resulting in a narrow view of the digital divide, which creates a distorted picture of the divide. Furthermore, these benchmarks, which are typically developed in technologically advanced countries, may suffer from the opposite problem of the "highest common denominator," and may not be appropriate for countries that are behind technologically. The fixed and therefore arbitrary importance and weight that are given to each factor are a compromise that accommodates most countries or perhaps the strongest ones and does not reflect the real relations in each one of the countries. It is easier to look for basic elements of a digital divide (e.g., network connectivity), rather than delving into aspects that require an appreciation of context and may call for differentiation. For example, it is meaningless to ask for factors of usage in a country where connectivity is almost zero or to ask about affordability of infrastructure in countries that give it for free. In sum, this article argues that context should be one of the most important frameworks when conceptualizing the digital divide and constructing an index.

Another challenge that decision makers face is the limited number of "ready-to-use" tools for assessing a nation's digital divide (Bridges.org, 2005a). According to Bridges.org (2005a), "there is a wide range of reports and other resources that can be re-worked into assessment tools" (p. 2) but there are not many ready-to-use tools. More "ready-to-use" tools would give decision makers incentives to consider factors more diverse than infrastructure oriented.

Moreover, the literature is full of single-issues studies that are local and tied to a specific context. Monotopical measures of digital divide typically identify one or a few variables that influence a dependent variable, which, in turn, reflects one aspect of the divide, such as awareness, access, attitudes, or application. Each of these may serve as a gauge of the gap. Among these mono- or single topics, the literature mentions the following: income (Ebo, 1998), occupation (Losh, 2004; McLaren \& Zappalà, 2002), gender and age (DiMaggio et al., 2004), education (Cornfield \& Rainie, 2003), geographic centrality (Chen et al., 2003; Cornfield et al., 2003), ethnicity and race (Hoffman et al., 1999; 2000; Novak et al., 1997), religiosity (Bell et al., 2004), language (Foulger, 2001), family structure (Kennedy et al., 2003), physical capacity (Le Blanc, 2000; Lenhart et al., 2003), frequency (Fox, 2004), time online (Spooner \& Rainie, 2001), purpose (Center for the Digital Future, 2004), skills (Robinson et al., 2003), autonomy (Dasgupta et al., 2002), affordability (OECD/DSTI, 2001), competitive market structure (Dutta \& Jain, 2004), ownership and density of computers and web sites (Sicherl, 2003), and communication infrastructure (Horrigan \& Rainie, 2004; Horrigan, 2004a, 2004b; Katz et al., 2003; Wareham et al., 2004).

Monotopical subjects are important as ends by themselves, but not when they serve as the mean or as the only common denominator. I believe that context and ability to compare are not mutually exclusive concepts. So the first challenge to confront when conceptualizing a complex concept like the digital divide is to ask, "What is the purpose of the tool being constructed?" Instead of falling into the trap of the common denominators in all nations, I suggest an index that takes into account the context of the digital divide in each nation. That is, each nation will have factor weights that reflect its specific context and needs, but the overall concept would be what is ultimately compared. If the purpose of the tool is to compare connectivity, do not look for an index that reflects the digital divide; look instead for one that simply compares this monotopical subject without entering into context consideration. But if the purpose is to reflect the digital divide, then context has to be included. For example, countries that do not have infrastructure will put more weight on infrastructure factors, while countries that already have good connectivity will put the weight on other factors, like usage or political context.

Finally, I would like to note that networks and other technologies are nonneutral spaces, and this nonneutrality means that a contextual index is superior to other types of indices. The Internet, arguably one of the most representatives of the information society technologies, with its different levels of applications, creates a space of human interaction that is not neutral. The Internet is nonneutral, not only in its content and logical layers, but also in its foundations and structure (Barabasi, 2001; Cohen, 2002). Any conceptualization of the digital divide that ignores looking at the Internet as social and political spaces will 
have limited utility. Fortunately, consciousness about the Internet as a social and political space is starting to arise in academia and other sectors (for example, see the Access to Knowledge conference in Yale in 2006, where Jack Balkin and Yochai Benkler announced the beginning of a new movement, the social movement). ${ }^{3}$ If one agrees with this perspective, then one is led to a contextual conceptualization of the digital divide.

Next let us consider another dimension-level of observation - that needs to be taken into account by policymakers when they make a decision about what kind of index (i.e., monotopical or comprehensive) to use and the characteristics of this tool.

\section{Level of Observation: At What Level Should We Measure?}

Unfortunately, most of the existing indices are almost exclusively at the international and national level. Nevertheless, digital inequalities exist in variety of other levels: sector, community, and individual levels (Dewan \& Riggins, 2005). The current focus on these higher levels of analysis short-changes detailed and vitally important data collection and analysis at more micro levels. For example, many communities within nation-states are far removed from the rest of the country with regard to information and communications technology (ICT) access and use. Such communities reshape ICT to their culture and norms. Barzilai-Nahon and Barzilai refer to this as cultured technology (Barzilai-Nahon, 2004; Barzilai-Nahon \& Barzilai, 2005). We cannot disregard the discrepancies at local levels and the variance in digital use in access, even if such variance is below the nation-state threshold, since in many cases this level of resolution is more meaningful than the national and international levels that tend to be more popular.

Our proposal is not to include all the levels in one index, but rather to use a similar index design for all levels, while the importance and weights of the different factors are altered according to the specific context. This would allow maximum flexibility in the level of measurement, whether it is at sector, communal, national, or international level. For example, an index measuring the digital divide in an immigrant community will emphasize weights that reflect language factors over other factors in the index.

\section{Method of Approaching the Data: Which Framework to Choose?}

In contrast to monotopical approaches for measuring the digital divide, integrated indices propose a more ambitious or encompassing prism but with more risks. Such integrative approaches have been proposed and implemented by various institutions and scholars. But not many "ready- to-use" integrated indices, or even reviews of assessment tools, exist. Yet these integrated indices are widely used (Bridges.org, 2005a; Grigorovici et al., 2002). Bridges.org (2005a) offers a comparison of the following assessment tools to determine e-readiness:

1. Ready-to-use questionnaires like these of CID (Center for International Development), APEC (Asian Pacific Economic Cooperation), or CSPP (Computer System Policy Project).

2. Case studies like those of USAID (U.S. Agency for International Development) and InfoDev (The Information for Development Program).

3. Third-party surveys and reports like KAM (Knowledge Assessment Methodology), MI (McConnell International's Risk E-Business), SIBIS (Statistical Indicators Benchmarking the Information Society), NRI (Networked Readiness Index), and more.

I do not assume that the e-readiness question overlaps the digital divide issue, and therefore I do not believe all the integrated assessment tools compared in the Bridges.org study would fit our discussion here. For example, I do not think that trust in e-commerce relates directly to digital divide. Moreover, that study also refers to tools that only partially measure e-readiness.

Prominent among the integrated indices are SIBIS (Statistical Indicators Benchmarking the Information Society), DIDIX (Digital Divide Index) (Dolnicar et al., 2003; Husing \& Selhofer, 2004), NRI (Network Readiness Index) (Dutta \& Jain, 2004), the Digital Access Index, and other more traditional inequalities measures such as the Gini Coefficient (Riccardini \& Fazio, 2002).

SIBIS, a project of the European Commission, is an ambitious large-scale effort that attempts to analyze and compare different indicators of digital divide (SIBIS, 2003). However, the SIBIS project has concentrated only on variables of access and use (SIBIS, 2003): computer use, Internet use, home access, Internet dropouts, broadband extensiveness, and more. Even indicators of readiness and awareness, which are more social and behavioral in nature than other indicators such as infrastructure and affordability, were constructed and operationalized from measures of access and use, not from social and psychological metrics. Moreover, all the indicators that were compared under SIBIS have been mainly monotopical or bitopical except the DIDIX, which was specially developed as a more comprehensive index and will be elaborated upon later. The comparison of various indicators, including the digital divide contained in SIBIS, demonstrated two trends: first, that there is a lack of emphasis on socioeconomic divides and social inequalities, and second, that there exists a need for a more comprehensive index. Although SIBIS moved forward from a monotopical toward an integrative stage, the index suggested was only partial. 
The second tool examined was DIDIX (Digital Divide Index), which was an attempt to construct a more integrative index by the SIBIS project (Husing et al., 2004; SIBIS, 2003). It concentrates on four "risk" groups, (i.e., women, people aged 50 and over, people with low level of education, people with low level of income). At the same time, DIDIX treats the digital divide from access and use perspectives only. Weights in the calculation of the integrative DIDIX index were assigned to each component that constructs the index (i.e., computer usage 0.5; Internet usage 0.3; and Internet usage at home 0.2). I identify at least three methodological flaws in this process: (1) Importance weights are assigned somewhat arbitrarily, (2) the risk groups are not mutually exclusive, and (3) the current form of constructing the index might obscure some internal dynamics at the national and lower levels of analysis (SIBIS, 2003). Consequently, it is important to construct a compound index where dynamics between the variables are taken into consideration.

The third tool I examined was the Digital Access Index that was proposed by the ITU (International Telecommunication Union) and considers the following factors: infrastructure, affordability, knowledge (adult literacy, and school enrollment), quality (bandwidth per capita and broadband subscribers), and usage (ITU, 2003). The greatest challenge and the largest payoff are in the construction of a unified index that reflects multivariate dimensions and illuminates both social and technological aspects. The construction of such a metric may prove valuable for policy formation, may contribute to public discourse, may aid rational decision making, and would of course be useful for research. In this context, the ITU's efforts to combine different aspects of digital divide into one index are especially appropriate. Nevertheless, the ITU has concentrated mainly on international differences and divides (ITU, 2003) and tends to overlook more local and micro levels of analysis, such as communities. The ITU has linked infrastructure factors with other factors like the factor of affordability (e.g., access price as percentage of gross national income per capita); the knowledge factor (examined through adult literacy and combined primary, secondary, and tertiary school enrollment); the quality factor (measured through international Internet bandwidth per capita and broadband subscribers per 100 inhabitants); and the usage factor (examined by looking at Internet users per 100 inhabitants). All of these measurements, therefore, are more aggregative at the international and national level rather than at the community and individual levels. My argument is that the digital divide is present and problematic at each of the individual, local, community, and sector levels as well as in the international arena, and therefore, a digital divide assessment tool should address, bridge, and measure at each of those levels.
The fourth assessment tool, the NRI (Network Readiness Index), is part of the Global Information Technology Report and was prepared by the World Economic Forum, INSEAD, and InfoDev. This Index seeks to find the degree of preparedness of a nation or community to participate in and benefit from ICT developments. Unlike the Digital Access Index, the NRI succeeds in offering an index that also analyzes communities, and not just national and international divides. The components that NRI takes into consideration are the environment for ICT, readiness of the community's key stakeholders (individual, business, and government) to use ICT, and the actual use of ICT among these stakeholders. NRI progresses further toward a full integrative measurement. The Achilles heel of the index is the issue I discussed earlier: NRI uses fixed arbitrary weights to assign the importance of the various factors and ignores the context and specific situation in the country or community it measures.

In sum, I argue that comprehensive indices are a result of serious investments and efforts, and some useful insights have been collected through the use of these indices (Chen \& Wellma, 2003; ITU, 2003). However, the integrative indices could benefit from a scientific validation of weights, reference to different levels, and reference to internal dynamics between the various variables. Constructing a composite measure for inequality poses several methodological and substantive challenges (Atkinson, 1970; Berrebi \& Silber, 1985; Gastwirth, 1972; Martin, 2003; Tichenor et al., 1970). When the inequality in question is expressed in monetary terms for the purpose of policy analysis and discussion, the issues may seem mainly statistical: For instance, does one focus on measures of centrality or variance? At the confluence of measurement and policy formation, one often encounters a tension between counting for decisions and counting for understanding. The (understandable) impatience of policymakers gets in the way of developing a deep understanding of the causes and long-term processes of divides and how these can be bridged. Conversely, scholarly insistence on reliability and validity often slow down much-needed intervention. In a way, this article is a call for greater patience from policy and research communities on matters concerning the digital divide. Policymakers and researchers need to converge on better measures, though this might take some time.

While I direct criticism toward the design of the index from a structural perspective (like validating weights, allowing application by different levels, and contemplating the internal dynamics between the various variables), attention should be placed on a serious examination of the ingredients used in measuring such a complex and controversial construct as the digital divide (Davison \& Shelia, 2003; Hoffman et al., 2000). The next section addresses this challenge and suggests the 
factors that should be included in the concept of the digital divide.

\section{DEFINING THE DIGITAL DIVIDE AND A FRAMEWORK FOR AN INTEGRATIVE INDEX}

There are many definitions of the digital divide. Chen and Wellman (2003) suggest a conceptualization based on factors of access and use, weighted by socioeconomic status, gender, life stage, and geographic location. Bridges.org (2001) proposes using the number of users or computers, infrastructure access, affordability, training, relevant content, information technology (IT) sector (size of ICT sector and integration into existing industries), poverty, and demographic lines (geography, race, age, religion, gender, and disability).

It is interesting to note that most of the indices mentioned earlier do not define and conceptualize up front the digital divide and subsequently operationalize their definition. Instead, they start their design process with variables and indicator levels and thereby enter the "loop of decision makers"; they are trying to come up with factors that are measurable, and they overlook what is truly meaningful in any particular context.

I would like to suggest a way to conceptualize the components of the digital divide and suggest a model that reflects interrelations among these factors. Table 1 is a compilation from diverse sources that refer to relations of indicators of the digital divide. ${ }^{4}$ This table illustrates the numerous theoretical, empirical, and summary attempts at defining and measuring the digital divide, and provides us with the basis for a comprehensive model and framework.

Table 1 lists potential factors for inclusion in a crosssector, cross-construct validation study of digital divide indices. This summary organizes the available literature and theoretical claims by sources of study, type of study, and origin of use for particular constructs.

Drawing from these studies and the summary in Table 1, I can generate a conceptual map of the interrelations of the above factors. This preliminary conceptualization is shown in Figure 1.

Figure 1 proposes a conceptual model of the causal relations that lead to the digital divide according to different atomistic studies that have been done in the area. The indicators mapped in Figure 1 suggest that we not only should take into account the direct relations of different indicators such as sociodemographic, accessibility, use, infrastructure access, affordability, and social and governmental support, but also should examine the interrelationships among the various indicators. For example, accessibility may affect the Digital Divide Index directly, but also affects it indirectly through the use indicator.

Each one of the factors presented in Figure 1 is an index by itself (hereafter named "factor index"). The factor indices were chosen after an extensive literature survey. The relationships among the different elements shown in Figure 1 have been proposed by different studies. Figure 1 integrates these relationships into one model (see also Albright, 2005). For example, in the factor index of use, we can find studies that measure how the length of time surfing online or frequency of surfing reflect the digital divide, but they do not measure the whole index that I refer to as "use" (e.g., (Cultural Access Group, 2001; Hargittai, 2002; Hoffman et al., 2000).

The model relies on the following relationships (acronyms as in Figure 1):

- SUP impacts the index directly-Most studies show that training and institutional support help in reducing the gaps (Bill \& Melinda Gates Foundation, 2004; Curtin, 2001; Foulger, 2001). Studies

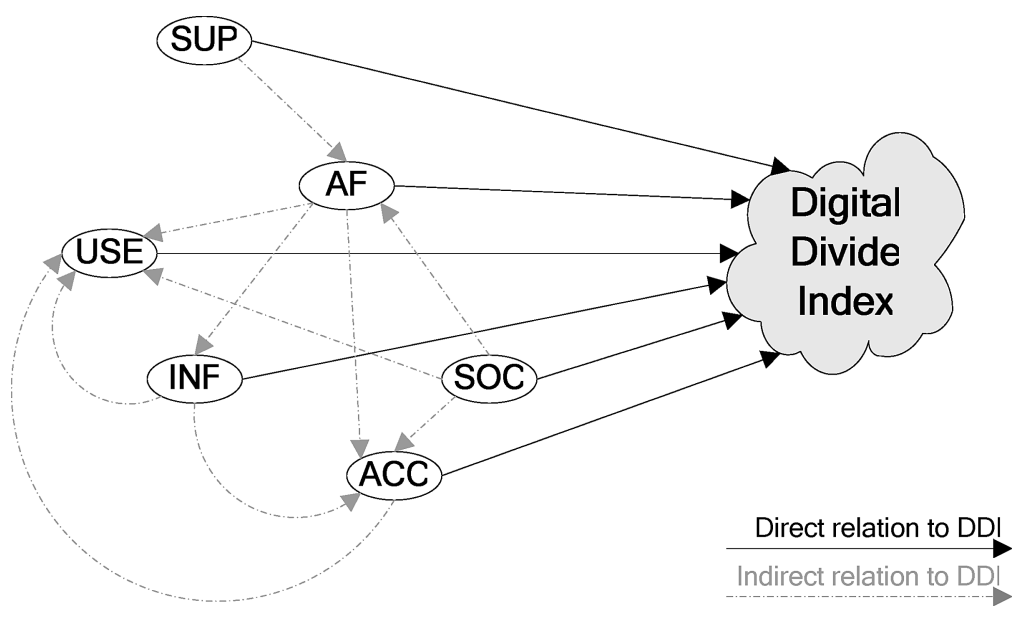

FIG. 1. Digital divide indicators relations modeling.

$\mathrm{SUP}=$ social and government constraints/support; $\mathrm{AF}=$ affordability; $\mathrm{USE}=$ use $\mathrm{INF}=$ infrastructure access; $\mathrm{ACC}=$ accessibility; $\mathrm{SOC}=$ sociodemographic factors. 
TABLE 1

Toward a comprehensive metric

\begin{tabular}{|c|c|c|c|}
\hline & Factor & $\begin{array}{l}\text { Type of } \\
\text { study* }\end{array}$ & Example studies \\
\hline 1 & $\begin{array}{l}\text { Infrastructure access } \\
\text { - Communication } \\
\text { channels and capacity } \\
\text { - Computers per capita } \\
\text { - Web sites per capita } \\
\text { - Number of ISPs per capita } \\
\text { - ISPs: governmental } \\
\text { incumbent or private }\end{array}$ & $\begin{array}{l}\text { PEC } \\
\text { PES }\end{array}$ & $\begin{array}{l}\text { (DiMaggio \& Hargittai, 2001; } \\
\text { Norris, 2004) } \\
\text { (Bridges.org, 2001; Chen \& Wellman, } \\
\text { 2003; Hoffman et al., } \\
\text { 2000; Husing \& Selhofer, 2004; } \\
\text { ITU, 2003; ITU } \\
\text { Telecommunication } \\
\text { Development Bureau, 2003) } \\
\text { (The Mosaic Group, 1996- } \\
\text { 2004; Warschauer, 2002) } \\
\text { (Horrigan \& Rainie, 2004) }\end{array}$ \\
\hline 2 & $\begin{array}{l}\text { Affordability (relative to other } \\
\text { expenditures and average income) } \\
\text { - Physical layer } \\
\text { (infrastructure) } \\
\text { - Logical layer } \\
\text { (applications and software) } \\
\text { - Content }\end{array}$ & $\begin{array}{l}\text { PEC } \\
\text { PES }\end{array}$ & $\begin{array}{l}\text { (Martin, 2003; Norris, 2004) } \\
\text { (Bridges.org, 2001; ITU, } \\
\text { 2003; ITU } \\
\text { Telecommunication } \\
\text { Development Bureau, 2003; } \\
\text { Martin, 2003) } \\
\text { (Cooper, 2002; The Mosaic } \\
\text { Group, 1996-2004) } \\
\text { (Lenhart et al., 2003) }\end{array}$ \\
\hline 3 & $\begin{array}{l}\text { Use } \\
\text { - Frequency } \\
\text { - Time online } \\
\text { - Purpose } \\
\text { - Users' skills } \\
\text { - Autonomy of use }\end{array}$ & $\begin{array}{l}\mathrm{T} \\
\text { PEC } \\
\text { PES }\end{array}$ & $\begin{array}{l}\text { (DiMaggio \& Hargittai, 2001; } \\
\text { Norris, 2004) } \\
\text { (Chen \& Wellman, 2003; Husing et al., } \\
\text { 2004; ITU, 2003; ITU } \\
\text { Telecommunication } \\
\text { Development Bureau, 2003) } \\
\text { (Warschauer, 2002) } \\
\text { (Crump \& McIlroy, 2003; Hargittai, } \\
\text { 2002; Lenhart et al., 2003) }\end{array}$ \\
\hline 4 & $\begin{array}{l}\text { Social and governmental } \\
\text { constraints/support } \\
\text { - Training } \\
\text { - Active help } \\
\text { - Support/suppression/apathy } \\
\text { - Investments and funding }\end{array}$ & $\begin{array}{l}\text { T } \\
\text { SE } \\
\text { PEC } \\
\text { PES }\end{array}$ & $\begin{array}{l}\text { (DiMaggio \& Hargittai, 2001) } \\
\text { (Chen \& Wellman, 2003) } \\
\text { (Warschauer, 2002) } \\
\text { (Crump \& McIlroy, 2003) }\end{array}$ \\
\hline 5 & $\begin{array}{l}\text { Sociodemographic factors } \\
\text { - Socioeconomic status } \\
\text { - Gender } \\
\text { - Age } \\
\text { - Education } \\
\text { - Geographic Dispersion } \\
\text { - Ethnic diversity } \\
\text { - Race diversity } \\
\text { - Religiosity } \\
\text { - Language }\end{array}$ & $\begin{array}{l}\text { T } \\
\text { SE } \\
\text { PEC } \\
\text { PES }\end{array}$ & $\begin{array}{l}\text { (Martin, 2003) } \\
\text { (Bridges.org, 2001; Hoffman } \\
\text { et al., 2000; Martin, 2003) } \\
\text { (Donnermeyer, 2003; The } \\
\text { Mosaic Group, 1996-2004) } \\
\text { (Bell et al., 2004; } \\
\quad \text { Lenhart et al., 2003) }\end{array}$ \\
\hline
\end{tabular}


TABLE 1

Toward a comprehensive metric (Continued)

\begin{tabular}{|c|c|c|c|}
\hline & Factor & $\begin{array}{l}\text { Type of } \\
\text { study* }\end{array}$ & Example studies \\
\hline \multirow[t]{4}{*}{6} & $\begin{array}{l}\text { Accessibility (disabled and } \\
\text { special needs populations) }\end{array}$ & $\mathrm{T}$ & $\begin{array}{l}\text { (Luke, in press; } \\
\quad \text { Perry et al., 1998) }\end{array}$ \\
\hline & & SE & (Kaye, 2000) \\
\hline & & PEC & $\begin{array}{l}\text { (Luke, in press; } \\
\quad \text { Waddell, 1999) }\end{array}$ \\
\hline & & PES & $\begin{array}{l}\text { (Kaye, 2000; } \\
\quad \text { Lenhart et al., 2003) }\end{array}$ \\
\hline
\end{tabular}

Note $. \mathrm{T},=$ theory papers; $\mathrm{SE},=$ secondary data empirical papers; $\mathrm{PEC},=$ primary data empirical papers that focus on cases; PES, = primary data, empirical papers, surveys.

also show that institutional constraints are definitely a factor in adopting and using the Internet. (Barzilai-Nahon \& Barzilai, 2005).

- SUP indirectly affects the index through AFInvestments in ICTs and funding projects by institutional agencies, according to studies, have a strong role in reducing the gap (Dutta et al., 2004).

- AF impacts the index directly-Studies show that as products, services, and content become more affordable, the digital divide is reduced (ITU, 2003). Most studies have concentrated more on analyzing affordability of infrastructure rather than content.

- AF indirectly affects the index through INF, USE, and ACC.

- SOC is correlated directly with the indexStudies show that different elements of sociodemographic factors are correlated to the gap. Among other factors, lower income (Bill \& Melinda Gates Foundation, 2004; Chinn \& Fairlie, 2003), lower education (Bell et al., 2004; Hargittai, 1999), living in rural areas (Drysdale, 2004; Flores, 2003), and affiliation with some ethnic groups (Bell et al., 2004; Novak et al., 1997) are associated with a higher digital divide.

- USE impacts the index directly-Most of the current studies actually concentrate on this factor (Center for the Digital Future, 2004; Cornfield \& Rainie, 2003). One also finds that most of these studies combine the use factor with sociodemographic subfactors.

- INF impacts the index directly-This is actually the traditional look at the factors that determine the digital divide.

- INF indirectly affects the index through USE, ACC - This type of relation is scarcely analyzed: how the use affects the digital divide while different infrastructure settings serve as a moderator variable.
- ACC impacts the index directly-This factor in many cases is neglected, and it refers to disabilities as widening gaps and the need to address special populations with physical disabilities (Kaye, 2000; Lenhart et al., 2003).

- ACC indirectly affects the index through USE.

\section{FACE TO THE FUTURE: NOT REPEATING HISTORY}

I claim that technology is not a neutral artifact in society. Rather, technology and its various facets should be comprehended and explicated within a given context. It is part of daily politics and social life, and as such it should be approached as a social and behavioral phenomenon. In this article I argue that the policymakers are inclined toward erroneous policymaking on the subject of the digital divide. I suggest three dimensions-purpose of the tool, level of observation, and method of approaching the data-that should be taken into significant consideration when policymakers are deciding on types and characteristics of measurement tools that they should use. Even existing "ready-to-use" tools that are more comprehensive than monotopical indices lack certain significant characteristics, which are analyzed in the article.

The conceptual framework proposed in this study should be considered a call to arms for a more comprehensive approach for measuring the digital divide. This article is by no means the final word or a comprehensive survey of global digital divide(s). If we are serious about understanding the complexity of the digital divide, further efforts that build on the model presented above are required. International cooperation to construct a data set specifically for each of the factors outlined in Table 1 would provide the basis for refining the model. A refined model would enable more informed policy decisions at the international, national, local, and personal levels. 


\section{NOTES}

1. In monotopical studies, researchers examine how certain factors have an impact on a certain aspect of the digital divide (e.g., how did low-income factors affect the use of technologies?).

2. This comment was made in a press conference on 8 February 2001.

3. See Benkler's and Balkin's speeches in the plenary session on 21 April 2006 in the Access to Knowledge conference at Yale University (http://research.yale.edu/isp/eventsa2k.html).

4. Due to lack of space, only examples of relevant literature are provided here.

\section{REFERENCES}

Albright, K. S. 2005. Global measures of development and the information society. New Library World 106(7/8):320-331.

Atkinson, A. 1970. On the measurement of inequality. Journal of Economic Theory 2(3):244-263.

Barabasi, A.-L. 2001. The physics of the web. Physics World, July 14. http://physicsweb.org/article/world/14/7/09

Barzilai-Nahon, K. 2004. Gatekeepers and gatekeeping mechanisms in networks, Management of Technology and Information Systems Program. Tel-Aviv: Tel-Aviv University.

Barzilai-Nahon, K., and Barzilai, G. 2005. Cultured technology: The Internet and religious fundamentalism. The Information Society 21(1):25-40.

Bell, P., Reddy, P., and Rainie, L. 2004. Rural areas and the Internet. Washington, DC: Pew Internet and American Life Project.

Benkler, Y. 2006. The wealth of networks. New Haven, CT: Yale University Press.

Berrebi, M. Z., and Silber, J. 1985. Income inequality indices and deprivation: A generalization. Quarterly Journal of Economics 100(3):807-710.

Bill \& Melinda Gates Foundation. 2004. Toward equality of access: The role of public libraries in addressing the digital divide. Seattle, WA. http://www.gatesfoundation.org/nr/Downloads/libraries/uslibraries/ reports/TowardEqualityofAccess.pdf

Bridges.org. 2001. Spanning the digital divide: Understanding and tackling the issues. Cape Town: Bridges.org. http://www. bridges.org/files/active/1/spanning_the_digital_divide.pdf (accessed 20 June 2006).

Bridges.org. 2005a. E-readiness assessment tools comparison (updated). Cape Town. http://www.bridges.org/files/active/0/ ereadiness_tools_bridges_10Mar05.pdf (accessed 20 June, 2006).

Bridges.org. 2005b. E-readiness assessment tools: who is doing what and where? (updated). Cape Town. http://www.bridges.org/files/ active/0/ereadiness_whowhatwhere_bridges.pdf (accessed 20 June 2006).

Center for the Digital Future. 2004. The digital future report: surveying the digital future, Year four: Ten years, Ten trends. Los Angeles: USC Annenberg School.

Chen, W., and Wellman, B. 2003. Charting and bridging digital divides: Comparing socio-economic, gender, life stage and rural-urban Internet access and use in eight countries. AMD Global Consumer Advisory Board (GSAB).

Chinn, M., and Fairlie, R. 2003. The determinants of the global digital divide: A cross-country analysis of computer and Internet penetra- tion. 38. Santa Cruz Center for International Economics, University of California, Santa Cruz, Working Paper.

Cohen, D. 2002. All the World's a Net. New Scientist 13 April. www.nd.edu/ networks/PDF/NSbarabasi.pdf. (accessed 20 June, 2006).

Compaine, B. M. 2001. The digital divide: Facing a crisis or creating a myth? Cambridge, MA: MIT Press.

Cooper, M. 2002. Does the digital divide still exist? Bush administration shrugs, But evidence says "yes." Consumer Federation of America, Consumer Union, The Civil Rights Forum, Washington DC. http:// chnm.gmu.edu/digitalhistory/links/pdf/introduction/0.26a.pdf. (accessed 20 June 2006).

Cooper, M. 2004. Expanding the digital divide \& falling behind on broadband: Why telecommunications policy of neglect is not benign. Consumer Federation of America, Consumer Union, The Civil Rights Forum, Washington DC. http://www.consumerfed.org/ pdfs/digitaldivide.pdf (accessed 20 June 2006).

Cornfield, M., and Rainie, L. 2003. Untuned keyboards: Online campaigners, citizens, and portals in the 2002 elections. Institute for Politics, Democracy \& the Internet. Washington DC: Pew Internet \& American Life Project.

Crump, B., and McIlroy, A. 2003. The digital divide: Why the "don't-wants-tos" wont Compute: Lessons from a New Zealand ICT Project. First Monday 8(12). http://firstmonday.org/issues/ issue8_12/crump/index.html (accessed 20 June 2006).

Cultural Access Group. 2001. Ethnicity in the electronic age: Looking at the Internet through a multicultural lens. Los Angeles, CA: Access Worldwide Communication Reports. http://www.accesscag.com/ pdf/internet\%20report\%20v.\%205.pdf (accessed 20 June 2006).

Curtin, J. 2001. A digital divide in rural and regional Australia? http://www.aph.gov.au/library/pubs/cib/2001-02/02cib01.htm (accessed 20 June 2006).

Dasgupta, S., Lall, S., and Wheeler, D. 2002. Policy reform, economic growth, and the digital divide. Policy Reform Working Paper of the World Bank no. WPS 2567. Washington, DC. http:// econ.worldbank.org/files/1615_wps2567.pdf (accessed 20 June 2006).

Davison, E., and Shelia, C. R. 2003. Connection discrepancies: Unmasking further layers of the digital divide. First Monday 8(3). http://firstmonday.org/issues/issue8_3/davison/index.html (accessed 20 June 2006).

Dewan, S., and Riggins, F. J. 2005. The digital divide: Current and future research directions. Journal of Association for Information Systems 6(2):298-337.

DiMaggio, P. and Hargittai, E. 2001. From the "Digital divide" to digital inequality: Studying Internet use as penetration increases. Princeton, NJ: Center for Arts and Cultural Policy Studies, University Working Paper 15.

DiMaggio, P., Hargittai, E., Celeste, C., and Shafer, S. 2004. Digital inequality: From unequal access to differentiated use. In Social inequality, ed. K Neckerman, pp. 355-400. New York: Russell Sage Foundation.

Dolnicar, V., Vehovar, V., and Sicherl, P. 2003. Advanced measuring of the digital divide: Multivariate interactions and digital distance, vol. 2004. University of Ljubljana, Slovenia.

Donnermeyer, F. J. 2003. Digital divide evidence in four rural towns. IT \& Society 1(4):107-117.

Drysdale, P. 2004. The new economy in East Asia and the Pacific. London: Routledge. 
Dutta, S., and Jain, A. 2004. The Networked Readiness Index, 20032004: Overview and analysis framework: 20. World Economic Forum.

Ebo, B. 1998. Cyberghetto or cybertopia?: Race, class, and gender on the Internet. Westport, CT: Praeger.

Flores, C. 2003. Measuring the relationship between ICT use and income inequality in Chile. Texas: University of Texas Inequality Project, Working Paper 26.

Foulger, D. 2001. Seven bridges over the global digital divide, IAMCR \& ICA Symposium on Digital Divide, Austin, TX. http:// evolutionarymedia.com/papers/digitalDivide.htm (accessed 20 June 2006).

Fox, S. 2004. Older Americans and the Internet. Washington, DC: Pew Internet and American Life Project.

Gastwirth, J. L. 1972. The estimation of the Lorenz Curve and Gini Index. Review of Economics and Statistics 54:306-316.

Grigorovici, D. M., Schement, J. R. and Taylor, R.D. 2002. Weighing the intangible: Towards a framework for Information Society indices. University Park, PA: Penn State eBusiness Research Center.

Hargittai, E. 1999. Weaving the Western web: Explaining differences in Internet connectivity among OECD countries. Telecommunications Policy 23(10/11):701-718.

Hargittai, E. 2002. Second-level digital divide: Differences in people's online skills. First Monday 7(4). http://firstmonday. org/issues/issue7_4/hargittai (accessed 20 June 2006).

Hargittai, E. 2003. The digital divide and what to do about it. In New economy handbook, ed. Jones, D.C. pp. San Diego, CA: Academic Press.

Hoffman, D., Novak, T., and Schlosser, A. 2000. The evolution of the digital divide: How gaps in Internet access may impact electronic commerce. JCMC 5(3). http://www.ascusc.org/jcmc/vol5/ issue3/hoffman.html (accessed 15 April 2005).

Horrigan, J., and Rainie, L. 2004. The broadband difference. Washington, DC: Pew Internet \& American Life.

Horrigan, J. B. 2004a. 28\% of Americans are wireless ready. Washington, DC: Pew Internet \& American Life press release. http://www.pewinternet.org/pdfs/PIP_Wireless_Ready_Data_0504. pdf (accessed 20 June 2006).

Horrigan, J. B. 2004b. Broadband penetration on the upswing: 55\% of Adult Internet users have broadband at home or work. Washington, DC: Pew Internet Project Data Memo. http://www.pewinternet. org/pdfs/PIP_Broadband04.DataMemo.pdf (accessed 20 June 2006).

Husing, T., and Selhofer, H. 2004. DIDIX: A digital divide index for measuring inequality in IT diffusion. IT \& Society 1(7):2138 .

International Telecommunication Union. 2003. ITU Digital Access Index: World's First Global ICT Ranking. Geneva: ITU. http://www.itu.int/newsarchive/press_releases/2003/30.html (accessed 20 June 2006).

ITU Telecommunication Development Bureau. 2003. Gauging ICT potential around the world. Geneva: ITU Publications. http://www.itu.int/ITU-D/ict/dai/material/DAI_ITUNews_e.pdf (accessed 20 June 2006).

Katz, J. E., and Rice, R. E. 2003. Comparing internet and mobile phone usage: Digital divides of usage, adoption, and dropouts. Telecommunications Policy 27(8-9):597-623.

Kaye, S. 2000. Computer and Internet use among people with disabilities. Disability Statistics Report (13). Washington, DC: U.S.
Department of Education, National Institute on Disability and Rehabilitation Research.

Kennedy, T., Wellman, B., and Klement, K. 2003. Gendering the digital divide. IT \& Society 1(5):1-25.

Le Blanc, J., and Anderson, R. 2000. Access and accessibility. Communications Policy and Practice 2(26).

Lebo, H. 2003. The UCLA Internet report: Surveying the digital future-Year Three: 89. Los Angeles: UCLA Center for Communication Policy.

Lenhart, A., Horrigan, J., Rainie, L., Allen, K., Boyce, A., Madden, M., and O'Grady, E. 2003. The ever-shifting Internet population: A new look at Internet access and the digital divide. Washington, DC: The Pew Internet \& American Life Project.

Losh, S. C. 2004. Gender, educational, and occupational digital gaps. Social Science Computer Review 22(2):152-166.

Luke, R. 2005. Access and accessability: Some notes on digital diversity. In Navigating the network society: The challenges and opportunities of the digital age, eds. S. Kretchmer and R. Carvety. Thousand Oaks, CA: Sage.

Martin, P. S. 2003. Is the digital divide really closing? A critique of inequality measurment in A Nation Online. IT \& Society 1(4): $1-13$.

McLaren, J., and Zappalà, G. 2002. The "Digital divide" among financially disadvantaged families in Australia. First Monday 7(11). http://www.firstmonday.org/issues/issue7_11/mclaren/index.html (accessed 20 June 2006).

Norris, P. 2001. The digital divide: Civic engagement, information poverty \& the Internet worldwide. Cambridge: Cambridge University Press.

Norris, P. 2004. The bridging and bonding role of online communities. In Society online: The Internet in context, eds. P. N. Howard and S. G. Jones, pp. 31-43. Thousand Oaks, CA: Sage.

Novak, T. P., Hoffman, D. L., and Venkatesh, A. 1997. Diversity on the Internet: The relationship of race to access and usage. Queenstown,MD. Paper prepared for the Aspen Institute's Forum on Diversity and the Media.

OECD/DSTI. 2001. Understanding the digital divide. OECD papers. http://www.oecd.org/dataoecd/38/57/1888451.pdf (accessed 20 June 2006).

Perry, J., Macken, E., Scott, N., and McKinley, J. 1998. Disability, inability and cyberspace. In Designing computers for people - human values and the design of computer technology, ed. B. Friedman, Stanford, CA: CSLI Publications.

Riccardini, F., and Fazio, M. 2002. Measuring the digital divide. IAOS Conference, London. http://www.statistics.gov.uk/iaoslondon2002/ contributed_papers/downloads/IP_Riccardini.doc (accessed 20 June 2006).

Robinson, J. P., Dimaggio, P., and Hargittai, E. 2003. New social survey perspectives on the digital divide. IT \& Society 1(5):122.

SIBIS. 2003. Sibis: New eEurope indicator handbook. European Commission publications. http://www.empirica.biz/sibis/files/ SIBIS_Indicator_Handbook.pdf (accessed 20 June 2006).

Sicherl, P. 2003. Different statistical measures provide different perspectives on digital divide. 6th ESA Conference. http://www.sicenter. si/pub/Sicherl_Digital_divide_Murcia.pdf (accessed 20 June 2006).

Spooner, T., and Rainie, L. 2001. Hispanics and the Internet. Washington, DC: Pew Internet and American Life Project. 
The Mosaic Group. 1996-2004. The global diffusion of the Internet project. http://mosaic.unomaha.edu/gdi.html (accessed 20 June 2006).

Tichenor P., Donohue, G., and Olien, C. 1970. Mass media flow and differential growth in knowledge. Public Opinion Quarterly 34:159170.

Waddell, D. C. 1999. The growing digital divide in access for people with disabilities: Overcoming barriers to participation in the digital economy. Washington, DC: U.S. Department of Commerce.

Wareham, J., Levy, A., and Shi, W. 2004. Wireless diffusion and mobile computing: Implications for the digital divide. Telecommunications Policy 28(5-6):439-457.

Warschauer, M. 2002. Reconceptualizing the Digital Divide. First Monday 7(7). http://www.firstmonday.dk/issues/issue7_7/warschauer (accessed 20 June 2006).

Warschauer, M. 2003. Technology and social inclusion: Rethinking the digital divide. Cambridge, MA: MIT Press.

Wilson, E. J. III. 2006. Why we need a negotiation model to explain Internet diffusion. Access to Knowledge Conference, Yale University, New Heaven, CT. 